\title{
Technical Note \\ Management of Water Losses in Water Supply and Distribution Networks in Turkey
}

\section{Türkiye'de İçme Suyu Temin ve Dağıtım Sistemlerindeki Su Kayılarının Yönetimi}

\author{
Ayşe MUHAMMETOĞLU ${ }^{1}$, Habib MUHAMMETOĞLU ${ }^{1}$, \\ Alev ADIGÜZEL ${ }^{2}$, Özlem İRITAŞ², Yakup KARAASLAN ${ }^{2}$ \\ ${ }^{1}$ Akdeniz University, Environmental Engineering Department, Antalya, 07058, Kampüs, \\ Antalya/Turkey \\ aysemuh@akdeniz.edu.tr,muhammetoglu@usa.net \\ ${ }^{2}$ Ministry of Forestry and Water Affairs, General Directorate of Water Management, 06510, \\ Yenimahalle-Ankara/Turkey \\ alevkoksal@ormansu.gov.tr, oiritas@ormansu.gov.tr, ykaraaslan@ormansu.gov.tr \\ Received Date: 16.11.2017, Accepted Date: 15.01.2018
}

\begin{abstract}
Water losses in water supply and distribution systems have been a serious problem in Turkey and all over the world causing economic costs and environmental drawbacks. Total water losses is the summation of real (physical) and apparent (commercial) losses. Main activities to reduce water losses include digitizing the components of network into Geographical Information Systems, dividing large water distribution networks into District Metered Areas, monitoring of flow rates and water pressures, carrying out yearly water balance, hydraulic modelling, pressure management, active leakage control, recording water consumption of the users, reducing meter errors and illegal water consumption. In 2014, the Ministry of Forestry and Water Affairs in Turkey issued a new regulation for water losses reduction, based on the methods used to determine and reduce the losses. This is followed by issuing practical description of the technical procedure to reduce the losses. The new legislation aims to reduce total water losses in all water authorities below $25 \%$ within certain time periods. All the water authorities in Turkey are required to carry out yearly water balance and report them to the ministry together with forms to follow up the efforts towards water losses reduction. In order to apply the prescribed techniques in a successful way, water losses problem should be understood well, technical and human resource capacity should be improved, and sufficient financial resources should be allocated. Also, the water utilities should have a strategic plan and a strong commitment to reduce water losses.
\end{abstract} balance

Keywords: physical water losses, apparent water losses, Turkey, regulation, standard water

\section{$\ddot{O} z$}

İçme suyu temin ve dağıtım sistemlerinde gözlenen yüksek orandaki su kayıpları, Türkiye'de ve tüm dünyada ciddi bir sorun teşkil etmekte; ekonomik ve çevresel olumsuz etkilere neden olmaktadır. Toplam su kayıpları, fiziki ve idari su kayıplarından oluşur. Su kayıplarının azaltılmasında etkin olan yöntemler içinde dağıtım şebekesine ait tüm elemanların Coğrafi Bilgi Sistemleri’nde tanımlanması, 
büyük şebekelerin alt bölgelere ayrılması, şebekede izleme yapılması, yıllık su dengesinin oluşturulması, hidrolik modelleme, basınç yönetimi, aktif kaçak kontrolü, abonelerin su tüketimlerinin düzenli olarak kaydedilmesi, sayaç hatalarının giderilmesi ve izinsiz tüketimin azaltılması yer alır. 2014 yılında Türkiye Cumhuriyeti Orman ve Su İşleri Bakanlığı tarafından içme suyu temin ve dağıtım sistemlerindeki su kayıplarının tespiti ve kontrolü için belirtilen yöntemleri içeren yeni bir yönetmelik yayımlanmıştır. 2015 yılında da su kayıplarının tespiti ve kontrolü için teknik bilgileri içeren teknik usuller tebliği yayımlanmıştır. Yeni yönetmelik ile tüm büyükşehir ve il belediyelerindeki su idareleri toplam su kayıplarını belirtilen süreler içinde $\% 25$ seviyesine indirmekle yükümlüdür. Tüm su idareleri yıllık su dengesi formlarını hazırlamalı ve bu formlarla birlikte su kayıplarını azaltmaya yönelik çalışmalarını Bakanlığa bildirmelidir. Belirtilen tüm unsurların başarı ile uygulanabilmesi için öncelikle sorunun yeterli düzeyde anlaşılması, teknik kapasitenin geliştirilmesi, altyapının yenilenmesi için yeterli mali desteklerin bulunması ve ilgili idari kurumun su kayılarını azaltmaya yönelik bir stratejik planının ve kararlılığının olması gereklidir.

Anahtar sözcükler: fiziki su kaylplarl, idari su kayıplarl, Türkiye, yönetmelik, standart su dengesi tablosu

\section{Introduction}

In recent years, water resources are under an increasing stress due to impacts of climate change, population increase and economic development. Water scarcity is recognized as a main threat particularly in the Mediterranean area. Thus, water utilities should become highly efficient throughout the entire water supply process, to guarantee sufficient quantities of good quality water. Since water is one of the most valuable natural resources, water losses in the Water Distribution System (WDS) represent an urgent problem that needs to be managed (Kanakoudis \& Muhammetoglu, 2014).

Water losses include Physical/Real losses and Apparent/Commercial losses (Figure 1). Water losses may occur at several points of a Water Supply System (WSS) including treatment works, trunk mains, service reservoirs, water meters and billing system. Water losses usually represent the biggest part of the so-called Non Revenue Water (NRW), which is the water that does not bring in revenues to the water utility. A World Bank study showed that approximately 45 billion $\mathrm{m}^{3}$ of water is annually being lost through leakage corresponding to $35 \%$ of the total water supplied. If half of this water was saved, 100 million people would have access to safe water without any further investment (World Bank, 2006). NRW has negative environmental (lost water and energy) and economic (lost revenues) impacts. Water losses imply greenhouse gases (GHG) emissions since the water volume being lost has been pumped, treated and distributed, using energy. Water losses related GHG emissions are even higher when desalination is used as the main water supply process (Kanakoudis \& Muhammetoglu, 2014). 


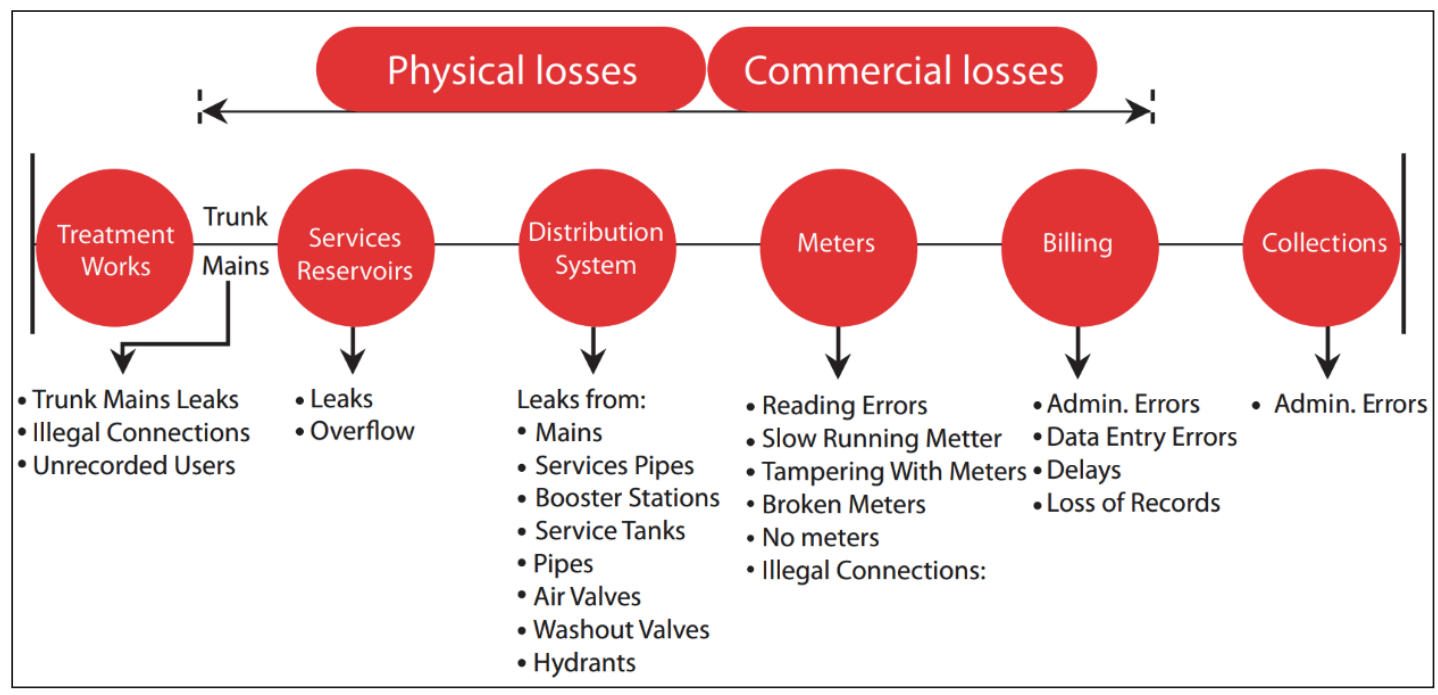

Figure 1. Typical losses from a water supply system (MNRW, 2008).

The share of physical and apparent water losses within total water losses shows great differences between countries. As an example, due to high levels of illegal water consumption in some African countries, the share of apparent losses within total water losses is higher than many other non-African countries. In general, approximately $60 \%$ of total water losses are comprised of physical losses and the remaining $40 \%$ are accounted for apparent losses (Muhammetoglu \& Muhammetoglu, 2017). Although NRW in Turkey was determined as $43.6 \%$ for the year 2012 according to the records of Turkish Statistics Institute (TSI, 2012), many municipalities in Turkey have no equipment to measure System Input Volume (SIV) which represents the total volume of supplied water to the WDS. Consequently, NRW estimations in many WDSs in Turkey are based on questionnaires and therefore they are not accurate (Güçlü, 2014). The percentage of NRW is reported to be less than $10 \%$ for some developed countries, but it could even exceed $70 \%$ for undeveloped countries (IBNET, 2017).

The main benefits of reducing water losses are reducing pumping and water treatment costs, increase in revenue water, delay of investments for new water infrastructure, postponing the need for new water resources, protection of water quality and reducing the risks of water borne diseases, reduction in frequency of pipe bursts and water cuts, service life extension of pipes and other equipment, and improving satisfaction of water subscribers. Understanding and quantifying NRW and water losses components is the first step for management of urban water losses. Additionally, water utilities should have a long-term commitment to develop a NRW reduction 
strategy. This paper briefly describes the fundamental principles for reducing water losses and improving operational efficiency in Turkey.

\section{Method}

This section presents the essential methods used to detect and reduce water losses.

\section{Water Balance}

Water balance calculation is basic for water losses determination and management and it is usually carried out in terms of volumes for one year. It shows the followings:

i. Volumes of physical and apparent water losses

ii. Volumes of the components of physical water losses (losses from reservoirs, losses from pipes) and components of apparent water losses (meter accuracy and data handling errors, illegal water usage)

iii. Volumes of the legal water consumption components (billed metered, billed unmetered, unbilled metered, unbilled unmetered)

iv. Volumes of water which reveals revenue. This is the volume of water that is billed.

\section{Dividing the Network into District Metered Areas}

It is difficult to manage water losses in a large Water Distribution Network (WDN) because the calculated water losses represent an average of the whole area. Therefore, it is a well-accepted procedure to divide a large WDN into smaller isolated areas, called District Metered Areas (DMAs), in order to manage water losses effectively and also to monitor water quantity and quality efficiently by noticing even the small variations of the water quantity and quality parameters. Water is supplied to each DMA at one or more locations where flow rates and water pressures are monitored and can be controlled (Figure 2). Consequently, the water balance at each DMA can be calculated and management measures can be effectively applied. 


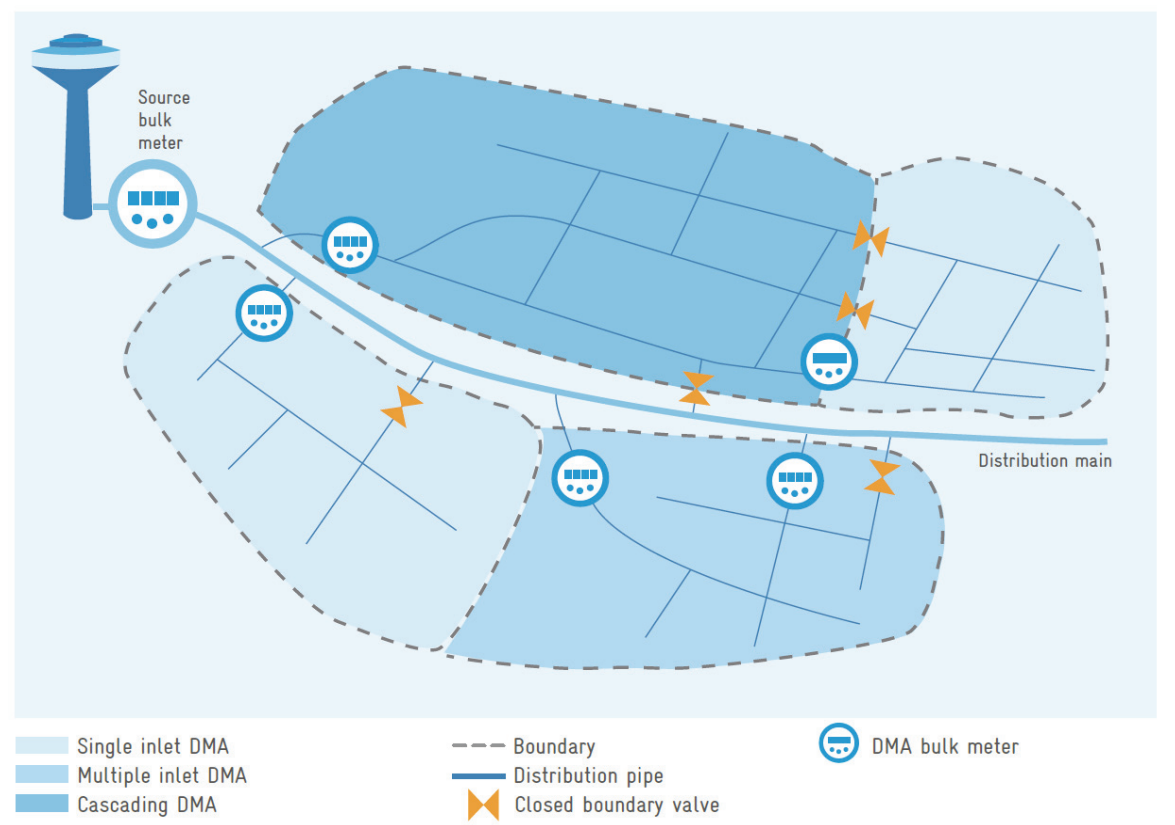

Figure 2. Typical DMA layouts (Farley, 2001; Fallis et al., 2011).

\section{Monitoring and Assessment}

Monitoring the flow rates, water pressures, levels of water in the reservoirs, and energy consumptions in WDNs is crucial to establish the water balance table, detect leakage, supply data sets to the hydraulic and water quality model and manage water losses. Many water authorities now have SCADA (Supervisory Control and Data Acquisition) system where many drinking water quality and quantity parameters are continuously monitored, analyzed and assessed by an integrated Real Time Monitoring (RTM)-SCADA system. The integrated system may also cover the pumping stations, balancing/service reservoirs, water sources and many stations located on the water mains. The system usually monitors water levels in the reservoirs, operation of pumps in the pumping stations and position of valves (open, closed, partially open) in the network in addition to energy and water consumptions (Figure 3). The display screen at the SCADA Center can show instantaneous water flow rate, stored water volume, instantaneous and previous day SIVs of water. Schematic presentation of data collection and transfer between key components of the system is presented in Figure 4. The monitored data sets are archived at the SCADA Center for evaluation and usage for hydraulic and water quality modelling applications. The system gives automatic alarms when the measured data sets are not within the predetermined limits. Also, it produces reports and charts for multipurpose analyses. It is important to monitor and 
assess minimum night flow (MNF) at each DMA. MNF is the lowest flow rate and it usually occurs between 02:00 and 05:00 in domestic areas. Tourism and industrial areas may show a different trend. Most of MNF in domestic areas represents leakage as the water usage during MNF is at minimum (Farley, 2001; Fallis et. al., 2011).

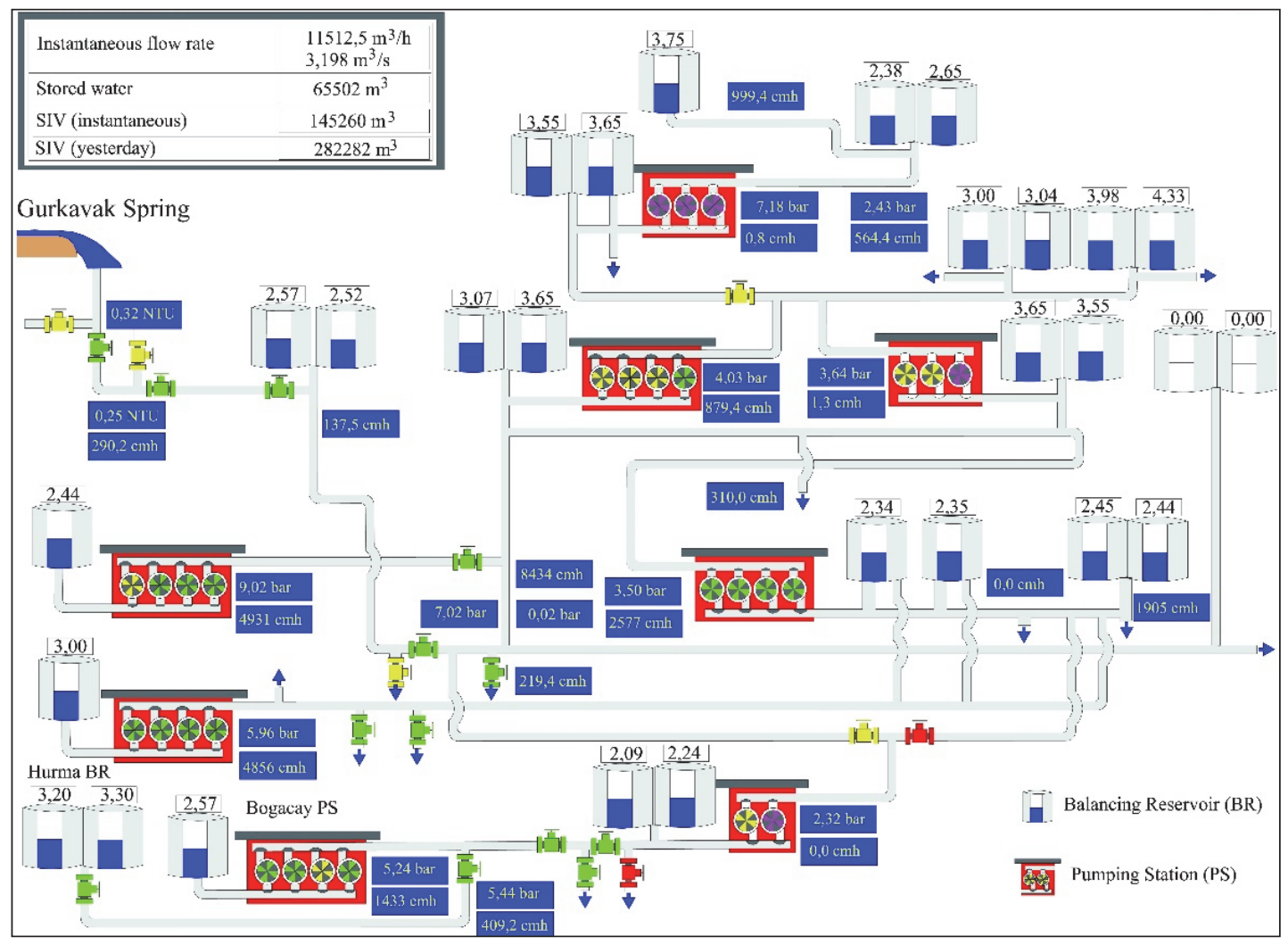

Figure 3. The general display screen of integrated RTM-SCADA system (Kara et al., 2016). 


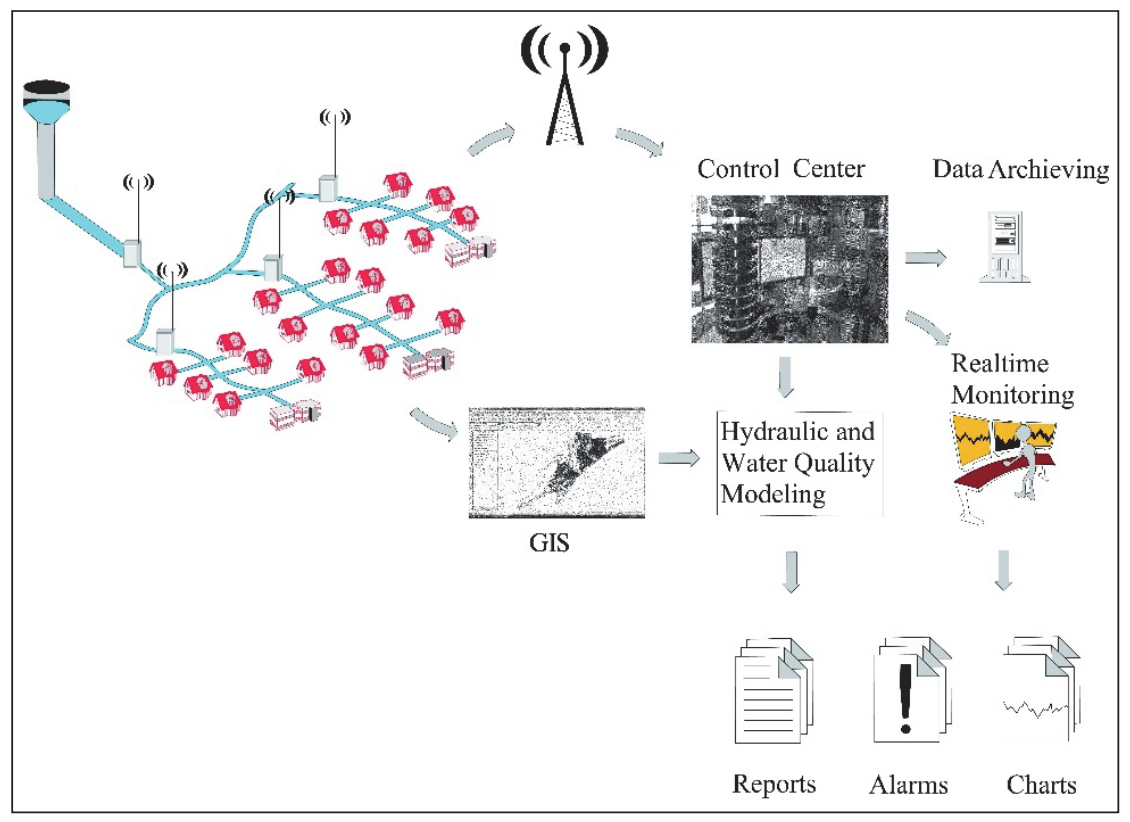

Figure 4. Schematic presentation of data collection, transfer and interpretation (Kara et al., 2016).

\section{Hydraulic Modelling}

Hydraulic modelling in WDN is used to predict the hydraulic parameters such as water velocity, flow rate and pressure. The predictions can be achieved at different locations in the network (e.g. at end points, the highest or lowest elevation, before or after the distribution reservoirs, etc.) and also at the desired seasons, dates (different days of the week) and times (different hours of the day). Thus, it is possible to predict the hydraulic parameters at space and time. Hydraulic modelling is a powerful tool to predict the impacts of different management scenarios on the hydraulics of WDN such as decreasing water losses and reducing water demands. However, hydraulic models should be well calibrated and verified by using different and numerous data sets collected through monitoring. Consequently, the models can yield reliable predictions.

\section{Pressure Management}

Water pressure in water distribution system is affected mainly by the elevation of the pipes, elevation of reservoirs and other elements besides pumping head (if any) and variation of water consumption. Variation of water consumption leads to variation in water velocity and hence variation in head losses (Morrison et al., 2007). As a result, 
water pressure usually shows considerable spatial and temporal variations. Therefore, the level of water pressure at some locations may not comply with the existing related regulations. Hydraulic models are efficient tools to predict the spatial and temporal variations of water pressures (Karadirek et al., 2012).

The WDN should be divided into a number of DMAs with suitable sizes in order to apply pressure management. Water pressure is usually measured at the entrance of the DMA and at the critical pressure points. Different types of Pressure Reducing Valves (PRVs) can be used to regulate the pressure at the critical points. Excess water pressure implies excess leakage from WDNs. Therefore, reducing water pressure alone leads to immediate reduction in leakage (Thornton \& Lambert, 2005). Moreover, avoiding excess water pressure has many benefits such as reducing pipe bursts and increasing service life of pipes and other equipment. Recently, a pump as turbine (PAT) has been applied for pressure reduction and energy production (Muhammetoglu et al., 2017a, b).

\section{Reducing Physical Water Losses}

The four pillars of a leakage management strategy include (i) pressure management, (ii) repairs, (iii) active leakage control, and (iv) asset management (Figure 5). The large square in the middle represents the Current Annual Real/Physical Losses, which tends to increase as the distribution network ages. But the rate of increase can be constrained by an appropriate combination of the four components of a successful leakage management strategy. Unavoidable Annual Real Losses (UARL) is the lowest technically achievable volume of physical losses at the current operating pressure. Introducing or strengthening any of the four components will have an effect on the potentially recoverable losses. 


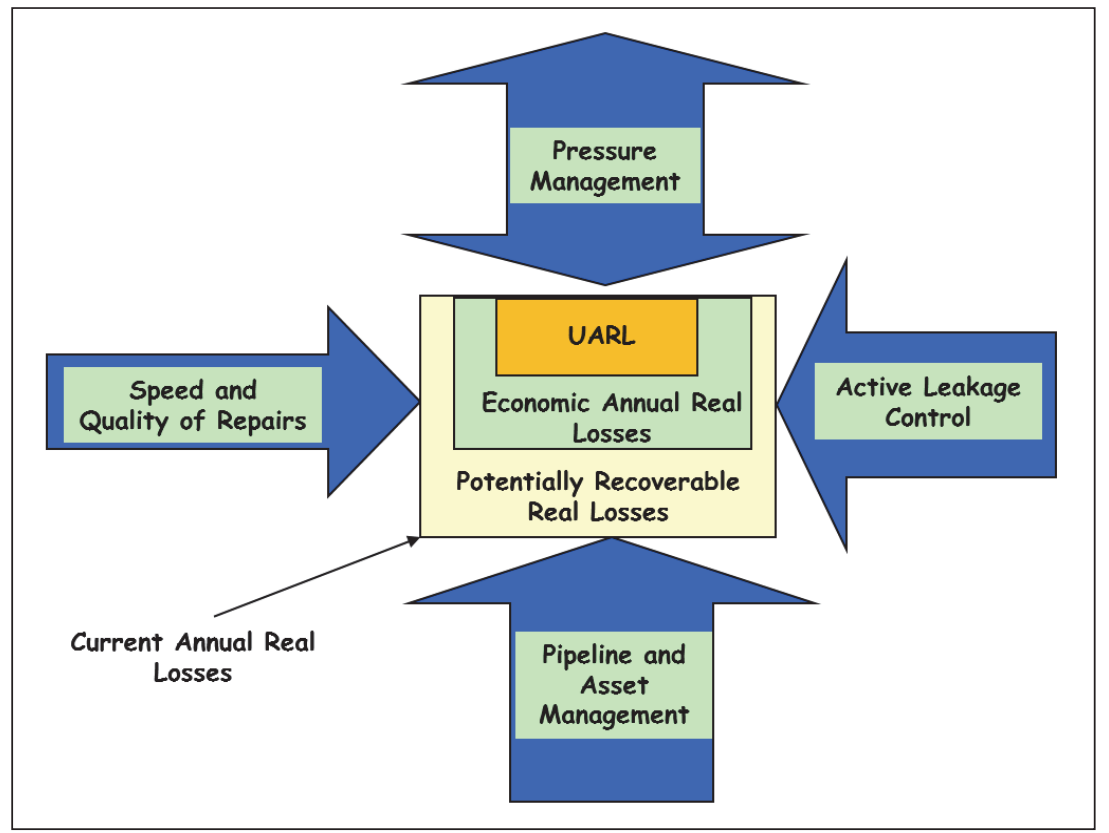

Figure 5. The four pillars of real water losses reduction (Lambert \& McKenzie, 2002) (UARL, Unavoidable Annual Real Losses).

\section{Reducing Apparent Water Losses}

Apparent water losses are not visible, which lead many water utilities to neglect apparent losses and focus on physical losses. However, reducing apparent losses increases revenue. Apparent losses can be divided into four basic divisions, namely: $\mathrm{i}$. customer meter accuracy, ii. illegal use (unauthorized consumption), iii. meter reading errors and iv. data handling and billing errors. In many cases, water passes through the meters but is not recorded accurately. The four pillars to reduce apparent water losses are depicted in Figure 6.

\section{Results and Discussion}

One of the main duties of General Directorate of Water Management, within The Turkish Ministry of Forestry and Water Affairs, is to establish policies and to prepare legislation regarding the prevention and sustainable use of water resources. Therefore, a department has been recently established within the directorate to improve water efficiency. The department gives utmost importance to reduce water losses from water supply and distribution systems in Turkey. A new regulation on water losses management "Control of Water Losses from Drinking Water Supply and Distribution 
Systems" was issued in May 2014 taking into consideration the methods used to detect and reduce water losses (OSIBB, 2014), which were described in the previous section. In July 2015, practical and technical procedure for detecting and reducing water losses was issued (OSIB, 2015). The new regulation obligates the metropolitan and provincial municipalities to reduce water losses to $30 \%$ within 5 years starting from 2014, and to $25 \%$ within the following 4 years. Regarding the other municipalities, water losses should be reduced to $30 \%$ within 9 years and to $25 \%$ within the following 5 years.

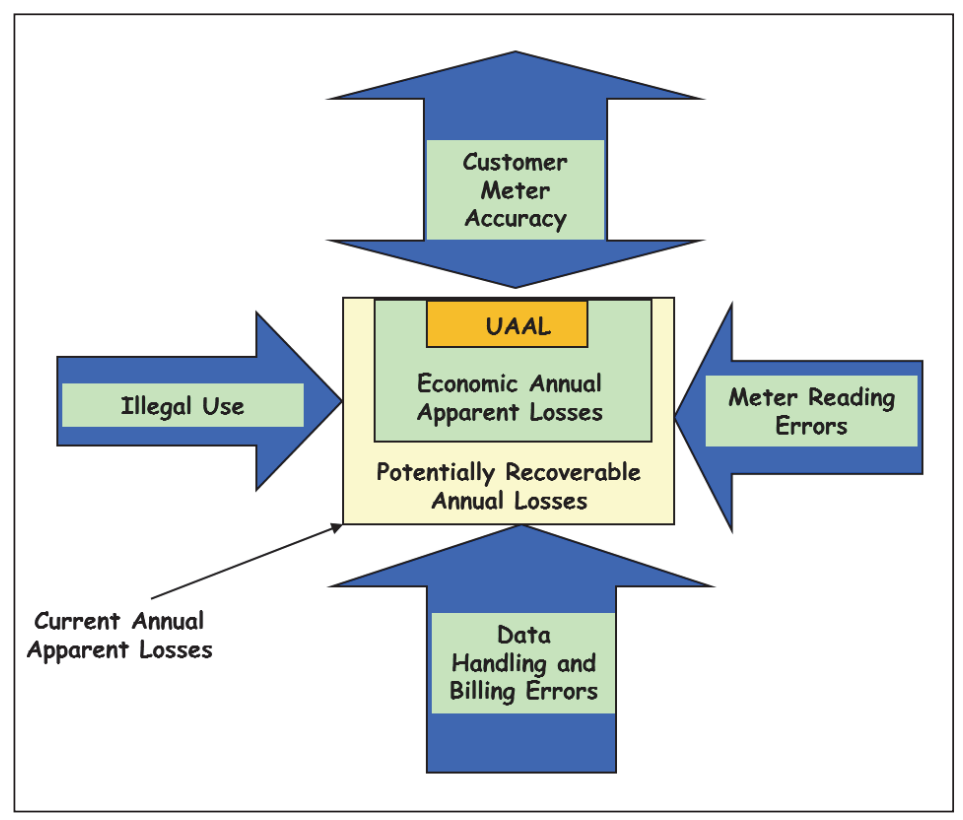

Figure 6. The four pillars of apparent water losses reduction (Rizzo et al., 2007; AWWA, 2009) (UAAL, Unavoidable Annual Apparent Losses). losses:

The following actions are listed in the regulation to detect and reduce water

- All water supplied to the network should be measured and recorded regularly.

- All water supplied to users should be measured by water meters. The water meters should be read and recorded regularly.

- The age of water meters should not exceed 10 years.

- Yearly water balance should be carried out and reported to the Ministry.

- The WDN should be divided into suitable number of DMAs, the new ones should be designed with DMAs. 
- All flows to the DMAs and critical pressure should be measured and recorded.

- Maximum water pressure head in WDN should not exceed $60 \mathrm{~m}$ if possible.

- The elements and data sets of the WDN should be digitized into Geographical Information System (GIS).

- Monitoring system (such as SCADA) should be established.

- Acoustic equipment should be used to reduce physical water losses.

- Hydraulic modelling should be carried out.

The water balance required by the Turkish regulation is slightly modified from the IWA (International Water Association) and AWWA (American Water Works Association) water balance (Alegre et al., 2006; AWWA, 2009) where the "leakage on transmission and distribution mains", and "leakage on service connections" components are combined in one component as presented in Table 1. This simplifies the components of the physical water losses because it is difficult to determine the two types of leakage separately and it is much easier to determine them as one component.

Table 1

Water Balance Showing Water Losses and NRW Components (OSIB, 2014)

\begin{tabular}{|c|c|c|c|c|}
\hline \multirow{8}{*}{$\begin{array}{l}\text { System Input } \\
\text { Volume }\end{array}$} & \multirow{4}{*}{$\begin{array}{l}\text { Authorized } \\
\text { Consumption }\end{array}$} & \multirow{2}{*}{$\begin{array}{l}\text { Billed } \\
\text { Authorized } \\
\text { Consumption }\end{array}$} & $\begin{array}{l}\text { Billed Metered } \\
\text { Consumption }\end{array}$ & \multirow{2}{*}{ Revenue Water } \\
\hline & & & $\begin{array}{l}\text { Billed Unmetered } \\
\text { Consumption }\end{array}$ & \\
\hline & & \multirow{2}{*}{$\begin{array}{l}\text { Unbilled } \\
\text { Authorized } \\
\text { Consumption }\end{array}$} & $\begin{array}{l}\text { Unbilled Metered } \\
\text { Consumption }\end{array}$ & \multirow{6}{*}{$\begin{array}{l}\text { Non-Revenue } \\
\text { Water }\end{array}$} \\
\hline & & & $\begin{array}{l}\text { Unbilled Unmetered } \\
\text { Consumption }\end{array}$ & \\
\hline & \multirow{4}{*}{ Water Losses } & \multirow[b]{2}{*}{ Apparent Losses } & Unauthorized Consumption & \\
\hline & & & $\begin{array}{l}\text { Customer Meter } \\
\text { Inaccuracies and Data } \\
\text { Handling Errors }\end{array}$ & \\
\hline & & \multirow[t]{2}{*}{ Physical Losses } & $\begin{array}{l}\text { Leakage on Transmission } \\
\text { and Distribution Mains, } \\
\text { and Service Connections }\end{array}$ & \\
\hline & & & $\begin{array}{l}\text { Leakage and Overflows } \\
\text { from Storage Tanks }\end{array}$ & \\
\hline
\end{tabular}

Recently, a handbook for managing water losses was written in Turkish and published in July 2017 (Muhammetoglu \& Muhammetoglu, 2017) with the financial 
and technical support of Ministry of Forestry and Water Affairs. The handbook includes ten chapters and several appendices with national and international practice examples. The handbook describes the methods used to detect and reduce physical and apparent water losses in a simple but practical way targeting the managers, decision makers, engineers, and technicians in the water administrations. Additionally, many water losses training sessions for the personnel of the water administrations were organized by the Ministry of Forestry and Water Affairs.

Municipalities in Turkey should aim for apparent water losses that are less than $10 \%$ of the authorized consumption. Reducing apparent losses requires a low level of investment with a short payback period, but it needs sustained management commitment, and community support. Municipalities in Turkey should focus on apparent losses in the beginning of water losses reduction program since the activities can be undertaken with little effort and the payback is fast.

Regarding the establishment of DMAs, it is important to ensure that all pipes into and out of the DMA are either closed or a flow meter is installed to measure the flow rates. Therefore, a zero pressure test should be applied to control if the DMA is hydraulically isolated or not. The test is carried out by closing all inlet valves to the DMA, and then ensuring that the water pressure within the DMA drops to zero after waiting for some time. The pressure should drop to zero because no water should enter to the DMA after closing the valves. If the pressure does not drop to zero, then it is possible that another pipe is allowing water to enter into the DMA.

Once the DMA has been established, the water balance table required by the water losses regulation should be prepared. For example, total water losses can be calculated as the difference between Total Inflow in DMA (System Input Volume) and Authorized Consumption in DMA. Total Inflow in DMA can be measured using the flow meter(s) installed at the entrance to the DMA and also at the exit of the DMA if any. Authorized Consumption can be calculated from all the customer meter readings assuming that all users are metered (as required by the regulation). It is essential to establish a record for all water subscribers in the DMA in order to calculate the legal water consumption of the DMA accurately. Leakage and overflows from storage tanks are not usually considered because most DMAs do not contain any reservoirs

Dividing a network into a number of DMAs creates many end points and may considerably change the hydraulic and water quality characteristics of the zone. In this respect, water pressures, flow velocities in pipes and residual chlorines may considerably change. Therefore, a hydraulic and water quality model should be used and applied to predict the changes as a result of dividing the network into DMAs. 
Accordingly, hydraulic and water quality modelling helps to choose the optimum design of the DMAs that yields the minimum drawbacks.

If all the authorized consumptions by the users are metered (as required by the water losses regulation) then the water balance table will be simplified and all the components of the authorized consumption will be determined based on measurements and not estimation. In practice, many water authorities face difficulties in estimating unmetered water consumption components in the water balance (billed or unbilled). This problem can be solved by installing water meters to all the users including the unbilled users such as religious facilities, parks and public toilets. However, converting all unmetered consumptions to metered consumptions may take some time and in some cases this may extend to years. The progress in this aspect should be recorded and monitored by the responsible institutions. Similarly, the SIV is not measured in many cases and rough assumptions are usually used for this purpose. Instead, SIV should be measured continuously and accurately all around the year. Some water authorities do not have enough financial resources to upgrade their infrastructure to measure the SIV but the yearly progress in this field should be recorded and reported.

The Turkish water losses regulation requires the water authorities to reduce water losses to certain levels within certain periods of time. The regulation mentions the key steps towards reducing water losses such as establishing the water balance, dividing the network into DMAs, digitizing the elements of the WDS into the GIS, monitoring, hydraulic modelling, etc. However, the infrastructure and human resources of many water authorities are very poor. Therefore, the yearly progress in the mentioned aspects should be monitored well in order to follow up the improvements in water losses reduction efforts.

The only performance indicator (PI) for water losses used in the Turkish regulation is the percentage value. It is easy to calculate and understand and therefore suitable to start with for water losses management. However, this PI is affected by the water consumption and does not take into consideration the number and length of service connections, length of the main pipes and water pressure. Also, this PI does not differentiate between physical and apparent water losses. Therefore, it is highly recommended to use additional PI such as the Infrastructure Leakage Index (ILI) which is widely used all over the world. ILI takes into consideration the existing physical water losses, number and length of service connections, length of the mains and the average operating pressure.

The water authorities should employ qualified engineers and training sessions should be organized to train the engineers on water losses issues, especially hydraulic 
modelling and pressure management. The developed hydraulic and water quality models need continuous updating because the WDS is dynamic and it shows continuous changes with time and space in terms of water consumptions, elements of WDS, quantity and quality of water resources, etc. The technical staff/engineers of the water authorities should be able to use and update the developed models. It is not practical to rely on the private sector for the development, updating and use of the models.

The water authorities should initially prepare the standard water balance table, calculate PI and the economic value of lost water to understand and control their water losses problem. A water authority should form a water losses control group and this group should have a clear water loss reduction strategy and targets. The strategy should include, among others, actions to reduce time for Awareness, Location and Repair (ALR) of leakages. Water authorities should follow a virtuous circle where investments are made to reduce NRW which in turn helps to increase revenues and decrease operational costs. In this way, there will be more revenues to spend for operational improvements and further NRW reduction programs. Furthermore, reduction of water losses is everyone's responsibility and raising public awareness is very important.

\section{Conclusion}

The recent water losses regulation, technical document and the handbook on control of water losses in water supply and WDNs are efficient steps to improve the current status of water losses reduction in Turkey. However, there are still some important lacking points such as the followings:

- Water balance calculations should be applied to each DMA of the WDN.

- It is important to employ qualified engineers capable of upgrading and using the GIS, hydraulic and water quality models of WDNs besides careful evaluation of the monitored parameters.

- The infrastructure needed to determine and reduce water losses such as measuring the SIV, installing water meters to the unbilled customers, GIS, DMAs, hydraulic modelling and pressure management should be upgraded.

\section{Acknowledgement}

The authors would like to thank Prof. Dr. Cumali KINACI, General Director of Ankara Water and Sewerage Authority, and Dr. Bülent SELEK, General Manager of General Directorate of Water Management for their valuable supports in this study. 


\section{References}

Alegre H., Baptista J.M., Cabrera E., Cubillo F., Duarte P., Hirner W., ... Parena R. (2006). Performance Indicators for Water Supply Services. Manual of Best Practice (2 ${ }^{\text {nd }}$ ed.). London, UK: IWA Publishing.

American Water Works Association. (2009). Water Audits and Loss Control Programs: AWWA Manual, M36. Denver: American Water Works Association.

Fallis, P., Hübschen, K., Oertle, E., Ziegler, D., Klingel, P., Knobloch, A., ... Laures, C. (2011). Guidelines for water loss reduction-A focus on pressure management. Retrieved from https://www.giz.de/fachexpertise/downloads/giz2011-en-guideline-water-loss-reduction.pdf

Farley, M. (2001). Leakage Management and Control. Retrieved from http://apps.who.int/iris/bitstream/10665/66893/1/WHO_SDE_WSH_01.1_eng.pdf

Güçlü, G. (2014). İçme Suyu Temin ve Dăğtım Sistemlerinde Su Kayıpları konulu sunum. Orman ve Su İşleri Bakanlığı, Türkiye'de Su Yönetimi ve Geleceği adlı Eğitim, 27-29 Kasım 2014, Afyonkarahisar.

IBNET. (2017). The International Benchmarking Network for Water and Sanitation Utilities, Knoema. Retrieved from

https://knoema.com/IBNNETWSU2011/the-international-benchmarking-network-for-water-andsanitation-utilities?tsId=1007880.

Kanakoudis, V. \& Muhammetoglu, H. (2014). Urban water pipe networks management towards nonrevenue water reduction: two case studies from Greece and Turkey. CLEAN-Soil, Air, Water, 42(7), 880-892.

Kara, S., Karadirek, I.E., Muhammetoglu, A. \& Muhammetoglu, H. (2016). Real time monitoring and control in water distribution systems for improving operational efficiency. Desalination and Water Treatment, 57(25), 11506-11519.

Karadirek İ.E., Kara S., Yılmaz G., Muhammetoğlu A. \& Muhammetoğlu H. (2012). Implementation of hydraulic modelling for water-loss reduction through pressure management. Water Resources Management, 26, 2555-2568.

Lambert A. \& McKenzie R. (2002). Practical Experience in using the Infrastructure Leakage Index. Lemesos, Greek Cypriot Administration: IWA Conference 'Leakage Management: A Practical Approach'.

MNRW. (2008). The Manager's Non-Revenue Water Handbook, A Guide to Understanding Water Losses, 2008. Retrieved from https://warrington.ufl.edu/centers/purc/docs/resources_NRWManagersHandbook.pdf

Morrison, J., Tooms, S. \& Rogers, D. (2007). District Metered Areas Guidance Notes. London, United Kingdom: IWA Publishing. 
Muhammetoglu, H. \& Muhammetoglu, A. (2017). İçme Suyu Temin ve Dağıtım Sistemlerindeki Su Kayıplarınin Kontrolü - El Kitabl. Retrieved from

http://suyonetimi.ormansu.gov.tr/Libraries/su/\%C4\%B0\%C3\%A7me_Suyu_Temin_ve_Da\%C4\%9F $\% \mathrm{C} 4 \% \mathrm{~B} 1 \mathrm{t} \% \mathrm{C} 4 \% \mathrm{~B} 1 \mathrm{~m}_{-}$Sistemlerindeki_Su_Kay $\% \mathrm{C} 4 \% \mathrm{~B} 1 \mathrm{plar} \% \mathrm{C} 4 \% \mathrm{~B} 1 \mathrm{n} \% \mathrm{C} 4 \% \mathrm{~B} 1 \mathrm{n} \_$Kontrol$\%$ C3\%BC_El_Kitab\%C4\% $\%$ B1.sflb.ashx

Muhammetoglu A., Karadirek I.E., Ozen, O. \& Muhammetoglu H. (2017a). Full-Scale PAT application for energy production \& pressure reduction in a water distribution network. A.S.C.E. Journal of Water Resources Planning and Management, 143 (8), DOI: 10.1061/(ASCE)WR.19435452.0000795 .

Muhammetoglu A., Nursen, C., Karadirek I.E. \& Muhammetoglu H. (2017b). Evaluation of performance and environmental benefits of a full scale pump as turbine system in antalya water distribution network. Water Science and Technology-Water Supply, DOI: 10.2166/ws.2017.087.

Orman ve Su İşleri Bakanlığı. (2014). İçme Suyu Temin ve Dă̆ıtım Sistemlerindeki Su Kayıplarının Kontrolü Yönetmeliği. (Resmi Gazete, Sayı: 289948 Mayıs 2014).

Orman ve Su İşleri Bakanlığı. (2015). İçme Suyu Temin ve Dağıtım Sistemlerindeki Su Kayıplarının Kontrolü Yönetmeliği Teknik Usuller Tebliği. (Resmi Gazete, Sayı: 2941816 Temmuz 2015).

Rizzo, A., Vermersch, M., St. John, S.G., Micallef, G. \&Race, R. (2007). Apparent Water Loss Control: The Way Forward. Water 21. London, England: IWA Publishing.

Thornton, J. \& Lambert, A.O. (2005). Progress in practical prediction of pressure: leakage, pressure: burst frequency and pressure: consumption relationships. Halifax, Nova Scotia, Canada: the IWA Specialized Conference "Leakage 2005".

Turkish Statistical Institute. (2012). Municipal Water Statistics, 2012. Retrieved from http://www.turkstat.gov.tr/PreHaberBultenleri.do?id=16171

World Bank. (December 2006). Discussion Paper No: 8. Retrieved from http://documents.worldbank.org/curated/en/385761468330326484/pdf/394050Reducing1e0water 0WSS81PUBLIC1.pdf 


\section{Extended Turkish Abstract \\ (Genişletilmiş Türkçe Özet)}

\section{Türkiye'de İçme Suyu Temin ve Dağıtım Sistemlerindeki Su Kayıplarının Yönetimi}

İçme suyu temin ve dağıtım sistemlerinde gözlenen yüksek orandaki su kayıpları, pek çok ülkede ve ülkemizde ciddi bir sorun teşkil etmektedir. Su kayıplarının azaltılması ile su kaynakları korunur (üretilen ve temin edilen su miktarı azalır), pek çok ekonomik kazanım (su alma, arıtma, terfi vb.) elde edilir ve su kaynaklı hastalık riskleri azaltılmış olur. Toplam su kayıpları, idari ve fiziki su kayıplarını içerir. Yeni içme suyu dağıtım şebekelerinde bile su kayıpları bulunmakta ise de bu oran gelişmiş ülkelerde \%10 seviyesinin altındadır. Ülkemizde içme suyu temin ve dağıtım sistemlerindeki su kayıpları oranı tahmin edilenden daha fazladır ve konuya özellikle su idareleri tarafından özel önem gösterilmesi gerekmektedir. Ülkemizde yürürlükte olan su kayıplarının kontrolüne ilişkin mevzuat ile içme suyu temin ve dağıtım sistemlerindeki su kayıpları oranının $\% 25$ 'e indirilmesi hedeflenmektedir. Son dönemde ülkemizde içme suyu temin ve dağıtım sistemlerindeki su kayıplarının belirlenmesi, azaltılması ve yönetimi çalışmaları önem kazanmış olup 2014 yılında Orman ve Su İşleri Bakanlığı tarafından "İçme Suyu Temin ve Dağıtım Sistemlerindeki Su Kayıplarının Kontrolü Yönetmeliği” ve 2015 yılında da aynı yönetmelik için Teknik Usuller Tebliği yayınlanmıştır. Bu makalede, ülkemizde içme suyu temin ve dağıtım sistemlerindeki su kayıplarının kontrolü açısından mevcut durum değerlendirilmekte ve su kayıplarının kontrolü açısından önem arz eden faaliyetler hakkında bilgiler sunulmaktadır.

İdari su kayıplarının azaltılması için abone tüketimlerine uygun boyutta ve yüksek ölçüm hassasiyetine sahip olan sayaçların kullanımı, büyük hacimde su tüketimi olan kullanıcılar için idari kayıpların dikkatle izlemesi, tüm su kullanıcılarına faturalandırma yapılmıyor olsa bile sayaç takılması, sayaçların doğru şekilde monte edilmesi, eskimiş ve arızalı sayaçların kullanılmaması, izinsiz tüketimlerin engellenmesi, sayaç okuma, işleme ve faturalama hatalarının sürekli olarak azaltılması önemlidir. Fiziki su kayıplarının azaltılması için de şebekede basınç yönetimi ve aktif sızıntı kontrolü uygulamaları, boru hattı (varlık) yönetimi ile onarım hızı ve kalitesinin iyileştirilmesi öncelikli faaliyetlerdir. Su kayıplarının etkin bir şekilde azaltılması için büyük içme suyu dağıtım şebekelerinin hidrolik olarak bağımsız, küçük alt bölgelere (DMA) ayrılması gereklidir. DMA oluşturma aşamasında DMA boyutu, DMA girişinde debi ve basınç ölçmek için ihtiyaç duyulan cihazların sayısı, DMA içindeki basınç değişimleri, DMA sınırları ve gerekli olan kapatma vanası dikkate alınmalıdır. Her DMA için, DMA içindeki tüm su kullanıcılarını içeren ayrı bir abone veri tabanı oluşturulmalıdır. DMA alanına giren su debisi sürekli olarak izlenmeli ve her DMA için minimum gece debisi analizi yapılarak sızıntı düzeyi takip edilmeli, boru tamiratı veya yenileme yapılması için değerlendirmeler yapılmalıdır.

Kentsel su kayıplarının azaltılması için önemli olan çalışmalar arasında su idareleri tarafından her yıl Standart Su Dengesi Tablosunun oluşturulması ve Orman ve Su İşleri Bakanlığı'na ulaştırılması büyük önem arz etmektedir. Bu tablo, su kayıpları bileşenlerinin anlaşılması ve ilgili bileşenler için uygun azaltma yönteminin seçilmesinde yardımcı olmaktadır. İçme suyu şebekelerinde uygun DMA'ların oluşturulması, boru bağlantılarının değiştirilmesi, su kayıpları seviyesindeki değişimlerin incelenmesi, hidrolik parametrelerin (debi, basınç, hız) tüm şebeke için zamansal ve mekânsal olarak analiz edilebilmesi amacı ile içme suyu dağıtım şebekeleri için hidrolik modelleme çalışması yapılmaktadır. Hidrolik model için gerekli olan pek çok girdi verisi Coğrafi Bilgi Sistemi ve izleme çalışmalarından elde edilmektedir. Fiziki su kayıplarının kontrolünde basınç yönetimi için farklı basınç düşürme vanaları kullanılabilmektedir. Basınç yönetimi ile şebekedeki fazla basıncın azaltılması, boru 
patlaklarının oluşma sıklığının azalması, şebeke elemanlarının kullanım sürelerinin uzaması vb. faydalar sağlanır. Veri tabanlı İzleme ve Kontrol Sistemi (SCADA) ve gerçek zamanlı izleme ile su miktarı ve kalitesi değişimleri görsel olarak izlenebilmekte, depo, pompa ve vanalar uzaktan kontrol edilebilmekte, boru patlakları tespit edilebilmektedir. Su kayıları seviyesi belirlendikten sonra her şebeke için uygun olan idari ve fiziki su kayıpları mücadele yöntemleri önceliklendirilerek hayata geçirilmektedir. Belirtilen tüm unsurların başarı ile uygulanabilmesi için öncelikle sorunun yeterli düzeyde anlaşılması, teknik kapasitenin geliştirilmesi, altyapının yenilenmesi için yeterli mali desteklerin bulunması ve ilgili idari kurumun su kayıplarını azaltmaya yönelik bir stratejik planının ve kararlılığının olması gereklidir. 